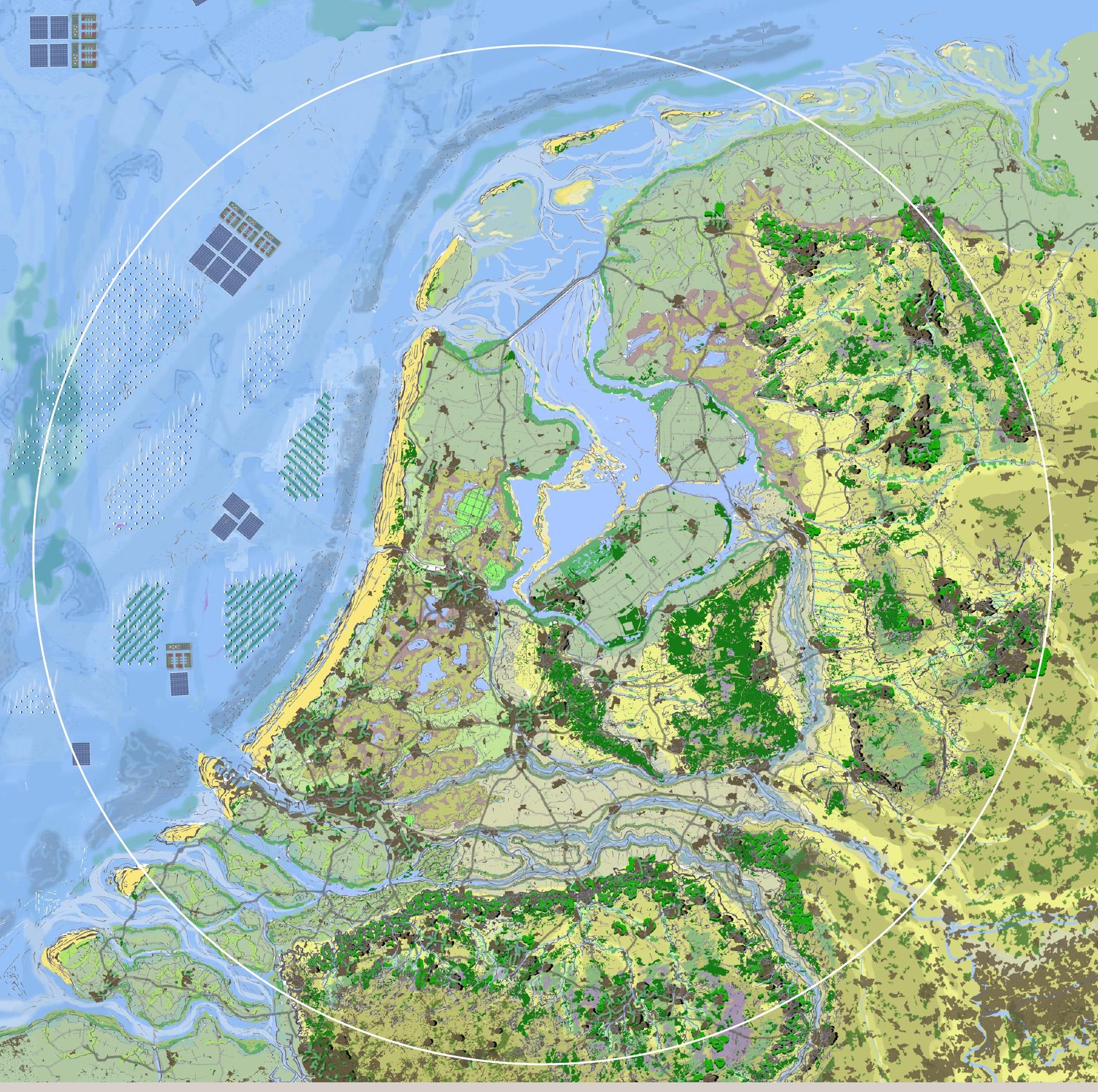

\title{
A nature-based future for the Netherlands in 2120
}

This project has been made possible by the Knowledge Base Program Nature Inclusive Transitions, project number KB-36-003-004 



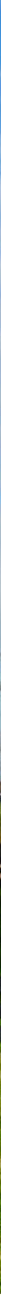

\section{What preceded}

In 2015, all United Nations Member States signed the Paris Climate Agreement, thereby committing themselves to limiting global warming to $1.5^{\circ} \mathrm{C}$, with a maximum of $2^{\circ} \mathrm{C}$ compared to the pre-industrial era. The treaty requires all countries to prepare an ambitious climate plan. If they do not take action, the limit of $1.5^{\circ} \mathrm{C}$ warming will already be exceeded in 2030 and the global temperature may increase by $3.2^{\circ} \mathrm{C}$ to $5.4^{\circ} \mathrm{C}$ at the end of the century. At those temperatures, sea levels will rise by 61 to 110 centimetres worldwide during this century and several meters in the subsequent century.

In 2018, the IPCC (the UN climate panel) calculated that it is possible to reduce greenhouse gas emissions to such an extent that global warming will be limited to $1.5^{\circ} \mathrm{C}$, with a maximum of $2^{\circ} \mathrm{C}$. In practice, however, implementation of the Paris Climate Agreement has been extremely difficult; many countries simply do not comply with the agreements. The harsh reality is that the use of fossil fuels and emissions of greenhouse gasses are still rising ${ }^{1}$. In 2019, major international research shook the world awake by concluding that global biodiversity is in steep decline ${ }^{2}$.

To turn the tide, all countries must commit to a nature-inclusive society and must take far-reaching measures to become energy-neutral by 2050 at the latest. At the same time, they must adapt to the effects of climate change and reverse the decline of biodiversity. What does this mean for the Netherlands? What are our challenges, what are our opportunities and what does a nature-inclusive future look like? 


\section{A new narrative for our country}

The Netherlands has always been able to adapt effectively to climate changes, but the rapid increase in greenhouse gas emissions and global warming due to human activity are unprecedented. The rising sea level, increase in extreme weather events and rising temperatures threaten the economy and wellbeing in our country. We face challenges that we have never faced before. We have to make a strong case for mitigation and adaptation, i.e. reduce greenhouse gas emissions and make adaptations to cope with the effects of climate change.

Wageningen University \& Research (WUR) has developed a vision for the future of the Netherlands in 2120. What can the Netherlands look like in a century, how will our country grow and flourish? What developments can we respond to over the next century to avoid or withstand extreme situations and growing uncertainties? What are the challenges, which transitions are needed and what solutions are possible?

\section{Nature takes the lead}

This vision for the Netherlands of 2120 specifies opportunities for the economy, biodiversity and liveability of our country. It is a new narrative for the Netherlands that gives leading roles to nature and natural processes. The story develops around the themes of water management, energy, agriculture, circular economy, urbanisation and biodiversity. By comprehensively approaching and analysing developments in these areas, we can work towards environmentally positive, nature-inclusive solutions.

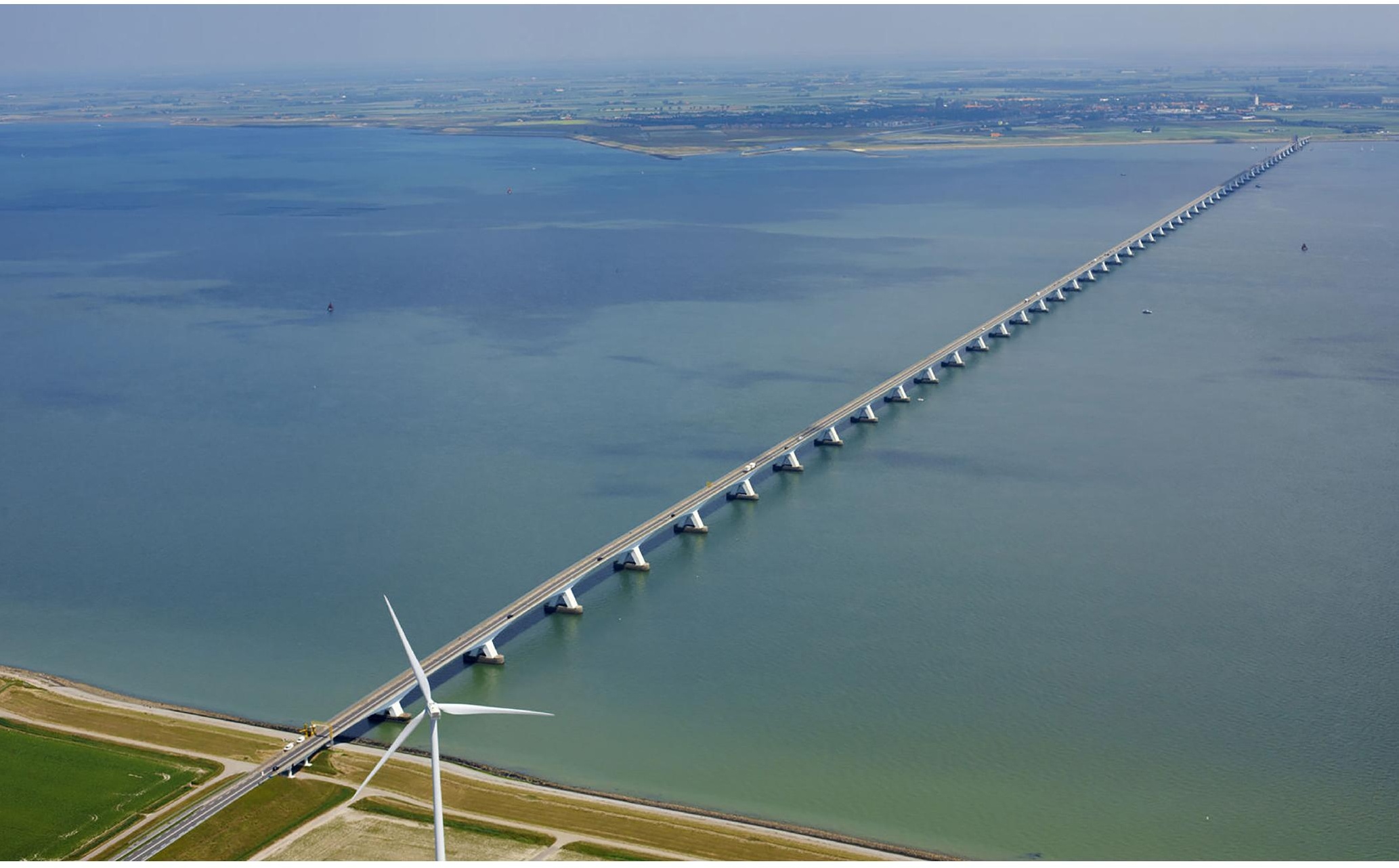




\section{The adaptation challenges for the Netherlands}

The Netherlands faces major adaptation challenges. Due to climate change, spatial planning and development in our country is becoming increasingly difficult. We are confronted with flooding due to weather extremes of precipitation, drought and heat waves, as well as accelerated subsidence of peat soils. The rising sea level increases the risk of flooding and rising water tables and leads to increasing soil salinization in coastal areas. The infrastructure that protects our country against these threats requires urgent adaptation. At the same time, there must be more room for alternative energy sources, and the increasing need for sustainable housing must be taken into account. Restoring biodiversity in the Netherlands requires a drastic intervention in intensive agriculture, a new perspective on urbanisation and spatial development, and smarter, more efficient and more sustainable water use.

\section{Renewable energy}

Worldwide, greenhouse gas emissions must be drastically reduced. By signing the Integral National Energy and Climate Plan (INEK), the Netherlands has committed to a reduction of 49 percent in 2030 compared to 1990 . Moreover, the energy supply in our country must be fully sustainable by 2050.

From 2050 onwards, we will only use solar and wind energy, geothermal energy and energy from other sustainable sources, such as biomass instead of fossil energy. The locations for extracting this renewable energy must be selected with care. They will receive a place where these activities disrupt nature and society the least, but still yield the most.

\section{Agriculture, horticulture, forestry and livestock farming}

The central theme of Dutch and European agricultural policy for more than half a century was to produce as much food as possible for the lowest possible price, while generating a liveable income for the farmer. In the meantime, the Netherlands has developed into the second agricultural exporter in the world. But complying with these environmental and climate agreements while meeting the increasing demand for food and other agricultural products and raw materials asks for a drastic change in direction. The future of Dutch agriculture, horticulture, forestry and livestock farming will be determined by the following aspects:

»Circular agriculture: minimal use of raw materials and energy, low impact on climate, environment and nature and a good income for the farmer.

» Nature-friendly livestock farming: fewer livestock, low-emission livestock housing, nature-friendly manure processing, new technologies for manure storage and fertilisation, and adaptation of animal feed to reduce methane emissions.

»Precision farming: less application of fertilisers, more frequent use of green fertilisers, less ploughing, more permanent grassland and more crops that retain $\mathrm{CO}_{2}$.

»Energy-efficient greenhouse horticulture: energy-saving technologies, switching from natural gas to sustainable energy and recycling energy.

»Climate-smart and nature-conscious management of peatlands, forests and arable farms: flooding peatlands, reforestation, planting drought-resistant and salt-tolerant crops and maximising carbon sequestration in agricultural soils.

\section{Circular and biobased economy}

Reusing products and recovering raw materials from waste are crucial for a sustainable future. Waste becomes the new raw material. Bio-refining has the potential to recover proteins, sugars, fats and other raw materials from biomass for the production of biobased materials, chemicals and fuels. 


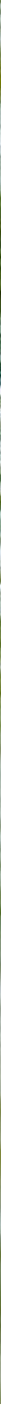

\section{The challenge for urbanisation and construction}

In the coming decade alone, one million housing units will be built in the Netherlands, most of them in the big cities. The Netherlands needs resilient spatial planning based on quality of life, good accessibility, sufficient production of sustainable energy, reduction of $\mathrm{CO}_{2}$ emissions and adaptation to the consequences of climate change.

\section{Restoring biodiversity}

Biodiversity is declining worldwide. An analysis by 500 experts from 50 countries $^{3}$ issued a warning about the worldwide extinction of 1 million plant and animal species. Human activity is the main cause of this mass extinction. Biodiversity is also declining in the Netherlands. To stop further deterioration and restore biodiversity, we must use natural resources more carefully and review our spatial planning practices. Because our country is situated in the delta region of major European rivers, we bear international responsibility for the conservation and restoration of biodiversity on land and in water.

\section{Water}

Due to climate change, we are more often faced with an excess or shortage of water, and with water at the wrong time or at the wrong location. This puts pressure not only on the liveability and safety of our cities and economic centres, but also on our biodiversity and societal resilience. In addition, salinization of our coastal areas is affecting water quality. This clearly demonstrates the importance of variation in water availability. 


\section{Five guiding principles}

The adaptation challenges in the Netherlands must be intelligently combined. The choices that we make for our vision of the future in 2120 are therefore based on five mutually reinforcing principles.

\section{The natural system as the starting point}

The type of soil, the differences in elevation and the water systems in the Netherlands will determine the future of spatial planning and development. The natural system is the starting point for the solutions that we propose for a climate-proof and biologically diverse country.

\section{Optimal use of water}

To enhance biodiversity and quality of the natural environment and to use every drop of water optimally, our water management focusses on maximum retention, utilisation and water storage, with wastewater disposal as the last resort.

\section{Nature-inclusive society}

We will take nature into account with all choices regarding energy, agriculture, circular economy, quality of life, urbanisation and water management. We look at the consequences of human actions for nature, protect 'old nature' more strictly and focus on natural processes, possibly in combination with technological solutions. We envision room for the emergence of new nature, making optimal use of human benefits (ecosystem services) and working on ecological connections that help flora and fauna to shift their distribution.

\section{Circular economy}

A more natural future for the Netherlands is based on the assumption that in 100 years the country will not only be climate neutral, but even climate positive, which means that we want to sequester more greenhouse gasses than we emit. This requires a transition towards a circular economy centred on sustainability, with a focus on services and a highly evolved, circular agricultural sector. At sea as well (aquaculture).

\section{Adaptive spatial planning}

The required adaptations to the effects of climate change, the energy transition, further urbanisation and increasing mobility lead to major changes in the environment and biodiversity. To ensure a safe, liveable, prosperous and sustainable future, the Netherlands must adapt intelligently to nature and make optimum use of natural processes in spatial planning. Examples of solutions include the 'Building with Nature' approach to flood risk management. 


\section{The Netherlands in 2120}

If we develop our vision for the future according to these principles, what will the Netherlands look like in 2120 ? Here is an overview.
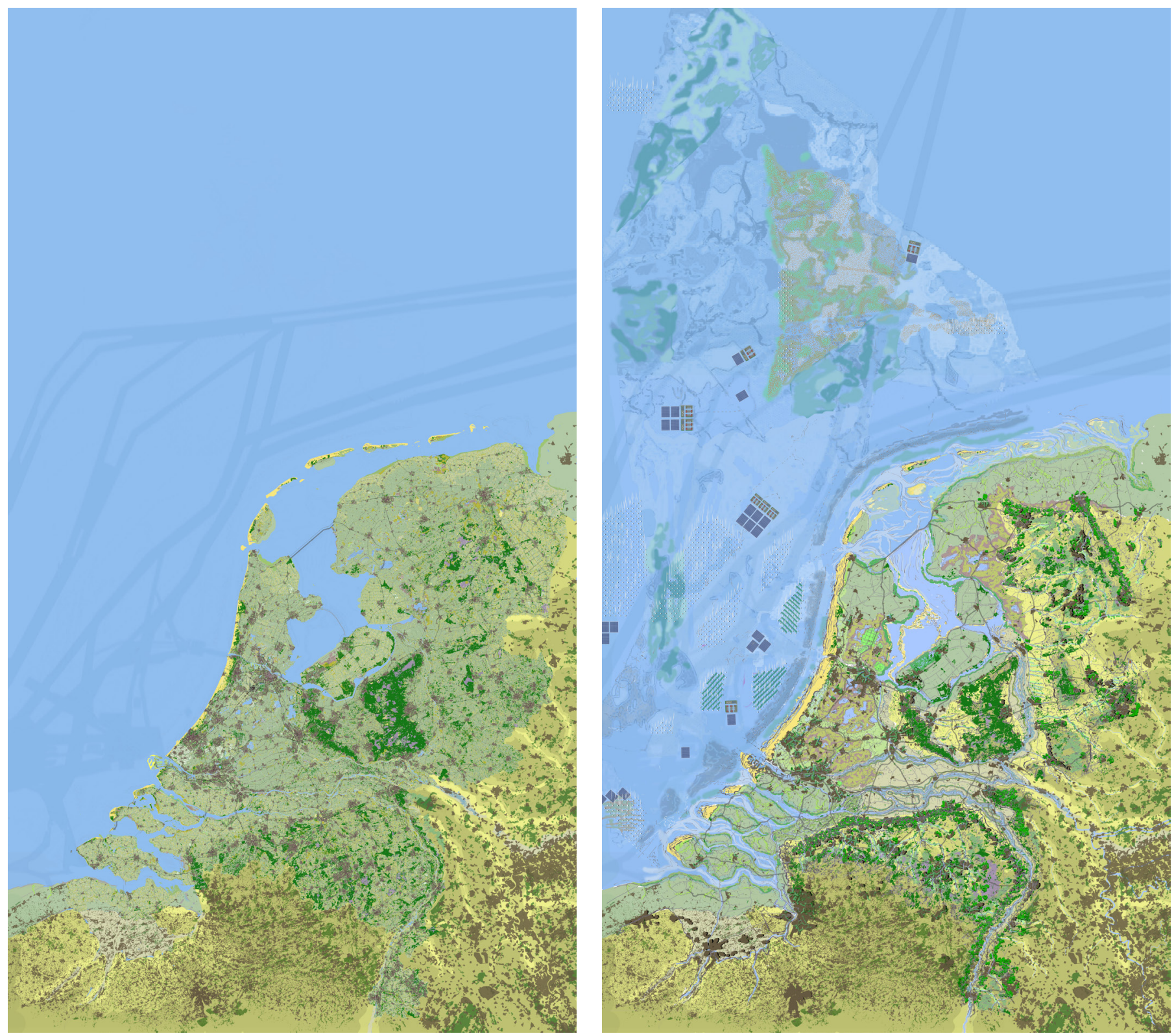

The map of the Netherlands in 2020 and the vision for the future in the Netherlands in 2120.

The population of the Netherlands will grow less rapidly in the coming century than in the past; in 2050 our country will have around 19 million inhabitants and in 2100 about 20 million. Our spatial planning and our use of land and water depend in the first place on what nature can support. One region will lend itself to an intelligent combination of agriculture and energy generation, while in other regions urbanisation will go hand in hand with the development of new natural habitats. In still other regions, protecting existing nature will be given priority and multi-purpose land use will not be an option.

\section{Blue-green landscape}

The urban environment and the agricultural landscape are interlaced with 'blue-green' landscape elements, such as green buffers along rivers and forests in urban areas. This not only results in a 
visually attractive landscape, but also has other benefits: it increases the area of natural habitats, woodlands and open water, it enhances biodiversity and provides more ecosystem services. It thus provides cooling, fertile soils and opportunities for recreation.

\section{Circular agriculture in 2120}

Dutch agriculture has become fully circular. By using innovative technologies (gene technology, nanotechnology, biotechnology, information technology and cognitive technology), crops are effectively and sustainably protected against pests and diseases, are more resistant to climate change, and are more nutritious and productive. Cities are surrounded by more trees and food forests (agroforestry), which will also sequester carbon and enhance the urban living environment.

Agriculture, horticulture and livestock farming intelligently anticipate salinization, waterlogging and weather extremes. In addition, farmers and growers have adapted to the changing dietary pattern of Dutch consumers, whether flexitarian or vegetarian. Insects and seaweed have been on the menu for some time. In 2120, the total agricultural production area is half of the area in 2020, and the production of livestock farming has shrunk by two-thirds. Some of the food production has been relocated to the sea.

\section{Biobased economy}

The Netherlands has developed into a climate-neutral, even climate-positive country. The Dutch economy of 2120 focuses on the sustainable use of natural resources and ecosystem services. Resources for biobased products and energy are extracted from biomass. The emission of greenhouse gases has been massively reduced and $\mathrm{CO}_{2}$ is sequestered in forests, soils, grasslands and wetlands. The area of woodlands has doubled in 2120 compared to now. Soils are fertile, absorb water plentifully and retain it for later use. Waste as such no longer exists, but has become the new raw material: almost everything we use is reused. Electric energy is cheap and sustainable and is generated entirely from the sun, wind, geothermal heat and biomass.

\section{The city}

The urban area of the Netherlands has increased in 2120. Cities are producing more energy and water than they consume. They act as a sponge for water and greenhouse gases; cities are 'green and blue' for optimum quality of life and cooling. The buildings are also nature-inclusive, and timber construction is commonplace. Purified wastewater from cities is used for drinking water, process water for industry and irrigation for agriculture. Rainwater is used optimally. In the last decades before 2120, water demand in the Netherlands decreased due to water-saving crops and water-saving measures. In addition to space for water and nature, the river area also provides space for floating homes. The 'climate dikes' along the rivers, which are much wider than today's dikes, provide locations for homes and sustainable energy generation.

\section{Policy}

Policy choices are reviewed for their effects on nature and biodiversity. Nature as a guiding principle is anchored in law and society. Comprehensive policy assessment and nature-inclusive policy is the norm. Nevertheless, there are still conflicts, in particular with regard to spatial planning allocations, land-use choices, the level of nature protection and the pricing of ecosystem services. A mediation and arbitration institute has been established to manage conflicts of interest and divergent views at the national level. International agreements are given priority in local and national policy. Free-riding is no longer an option. 
In 100 years from now, the Netherlands will be a land of green cities, circular agriculture, and more forests, water and swamps. A climate-proof Netherlands of this description is not just desirable but also feasible.

The Netherlands faces serious challenges. Our country is becoming less habitable due to falling biodiversity, rising sea levels, land becoming salinized or drying out, an energy problem, floods, a housing shortage, soil and plaques of insects. If we don't do anything, these problems will only get worse.

A new approach to exploiting natural resources and to spatial planning is necessary if we are to make a transition to a better, greener version of the Netherlands. A team of Wageningen researchers and designers developed a future vision for 2120 in which the forces of nature keep the Netherlands safe and prosperous.

The map illustrates a Wageningen version of the Netherlands in 2120 (see illustration). The vision is based on a number of criteria: for example, it had to deliver an optimal outcome for biodiversity, because only then can the country fundamentally thrive. And they had to work as much as possible with solutions in which there is a big role for natural processes. That meant producing an ideal picture, but it is definitely not a utopia. It is weighed up what was probable, what was possible and what was desirable. The result is a map of what is possible, i.e. feasible and realistic when Future choices on the use and layout of The Netherlands are based on understanding natural systems and processes.

\section{The North Sea}

\begin{tabular}{|l|l} 
development of aquaculture, \\
combined with wind energy production \\
$\begin{array}{l}\text { development oyster reefs and biodiversity } \\
\text { combined with wind energy production }\end{array}$ \\
$\begin{array}{l}\text { improving seabed and biodiversity } \\
\text { combined with wind energy production }\end{array}$ \\
nature reserves at sea
\end{tabular}

\section{The Coast}

sand mining
and seaward coastal defence

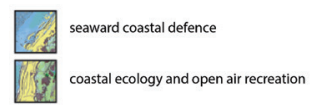

\section{The Wadden Sea}

\begin{tabular}{|c|c|}
\hline natural seaward coastal defence & $\begin{array}{l}\text { wide' 'soft' coastal defence } \\
\text { salt marshes, sandbars and dikes }\end{array}$ \\
\hline $\begin{array}{l}\text { new balance } \\
\text { drowned western part of the Waddensea }\end{array}$ & $\begin{array}{l}\text { new balance } \\
\text { active sedimentation managemen }\end{array}$ \\
\hline
\end{tabular}

\section{Lake IJssel}

$\begin{array}{lll}\text { strategic fresh water reserves } & \text { fresh water delta IJssel } \\ \text { development of islands to protect } \\ \text { dikes and improve shipping }\end{array}$

\section{The South-Western Delta}

'soft' coastal defence
combined with 'hard' infrastructure
development of fresh water reservoirs
in former creek soils
idouble dike' systems
and flexible polders

\section{Northern Clay Polders}

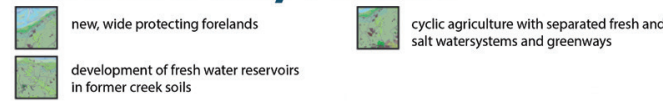

\section{Peat-meadow Areas}

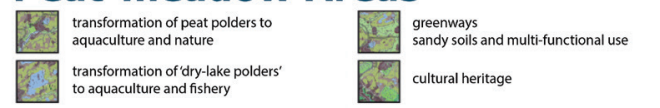

\section{The River Area}

widening river IJssel and increase of
its discharges

\section{The Pleistocene Sandy Areas}

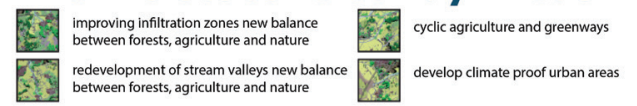

\section{Urban Areas}

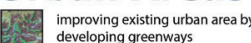
new nature and forest areas around urban
areas for recreation and dimate adaptation

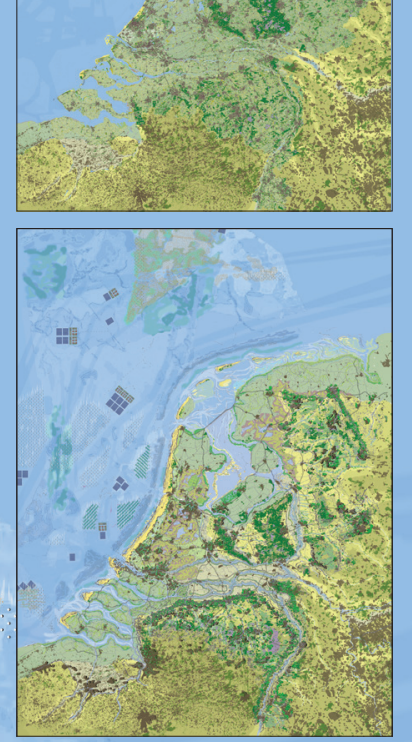




\section{The regions}

The Netherlands has a varied landscape of clay soils, peat soil grasslands, high-elevation and low-elevation sandy soils, lakes, rivers, river deltas, dunes, mud flats and the North Sea. In our choices for a climate-proof future for the Netherlands, we take account of the unique characteristics of each of these regions. For each region, what is needed per area to sustainably protect, conserve and enhance the Dutch landscape and ecosystems and ensure natureinclusive planning?

\section{The North Sea}

We need to do more with less land in our country and take more advantage of our coastal location, for example by making better use of the seabed, the water column and the water surface of the North Sea.

The North Sea has a lot to offer the Netherlands. It is not only a major producer of renewable energy, but also of protein from seaweed, shellfish and fish. In 2120, the energy and food production from the North Sea region is combined with nature development. Depending on the main function that is allocated to a specific area of the North Sea, for example protection of the seabed, another use is not permitted if it disrupts the main function.

\section{Renewable energy}

The North Sea is ideal for the production of sustainable energy at offshore wind farms and solar parks. The foundations of the wind farms provide good locations for natural reef builders, such as the flat oyster and the honeycomb worm. The resulting 'artificial' reefs provide habitats for many plant and animal species. On the foundations of the decommissioned installations for oil and gas extraction from the last century, floating islands are being developed for storing hydrogen gas and $\mathrm{CO}_{2}$ is sequestered in empty gas fields. Floating islands, on which ports, IT infrastructure and solar parks are also being built, have the great advantage that they rise with the rising sea level, are movable and can be easily removed at the end of their lifecycle.

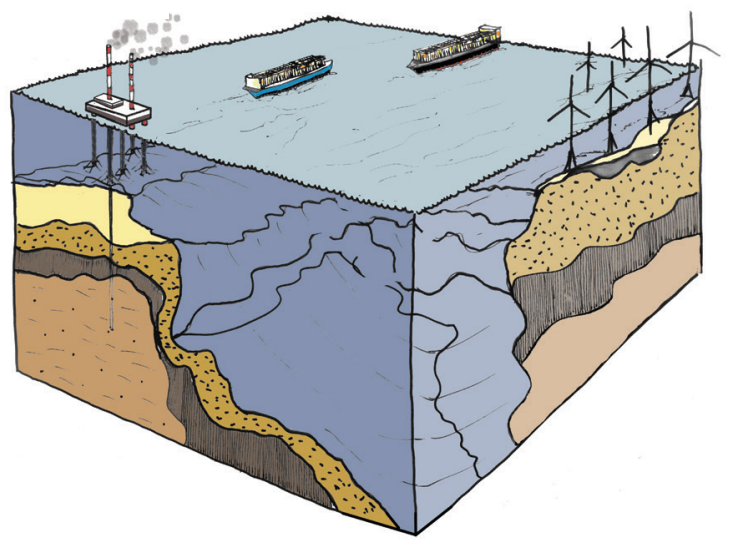

North Sea: existing situation

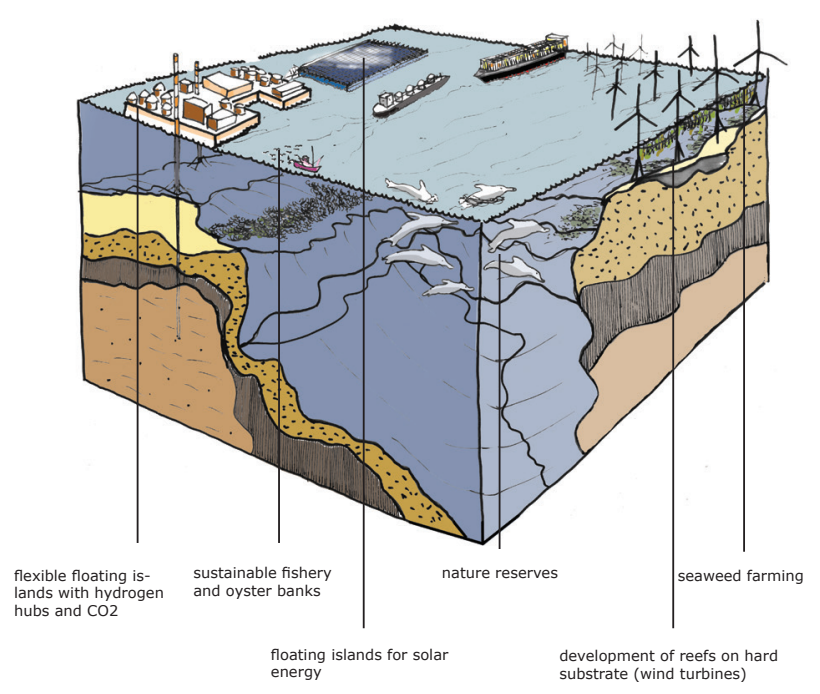

North Sea: future situation

\section{Food}

In 2120, people eat less protein from cattle and pork, which gives food production in and at sea a major boost. In the North Sea - especially at the wind farms - mussels, flat oysters and seaweed are cultivated (aquaculture). Fisheries have become completely sustainable; by-catch and seabed disturbance are kept to a minimum.

\section{Transport}

In 2120, ocean shipping has become one of the most sustainable forms of transport. Ships are partly propelled by wind, use hydrogen as a fuel and produce considerably less underwater noise. The burden of ocean shipping on the ecosystem of the North Sea is minimal.

\section{Water quality}

Potential pollution of the North Sea is tackled directly at the source, and improved wastewater treatment prevents harmful substances from ending up in the seawater. 


\section{Biodiversity}

As the water temperature rises, the North Sea has welcomed southern mammals and fish species such as the bottlenose dolphin, striped dolphin, blue shark, sea bass and John Dory. Fewer northern species live in the North Sea or have moved to deeper waters.

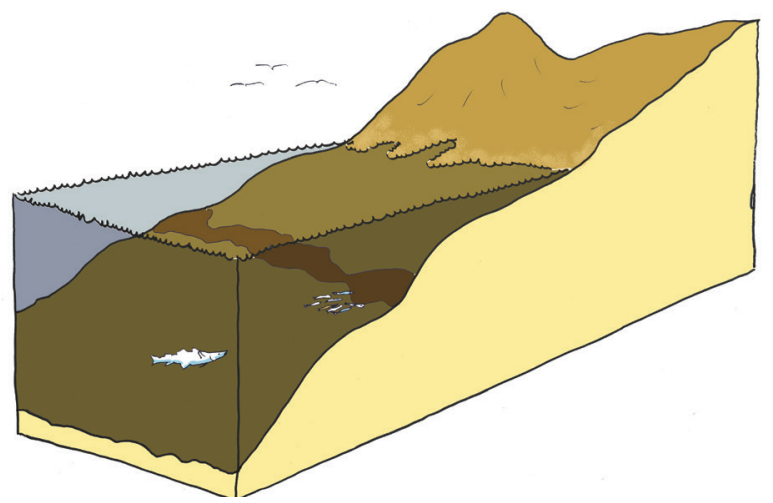

Coast: existing situation

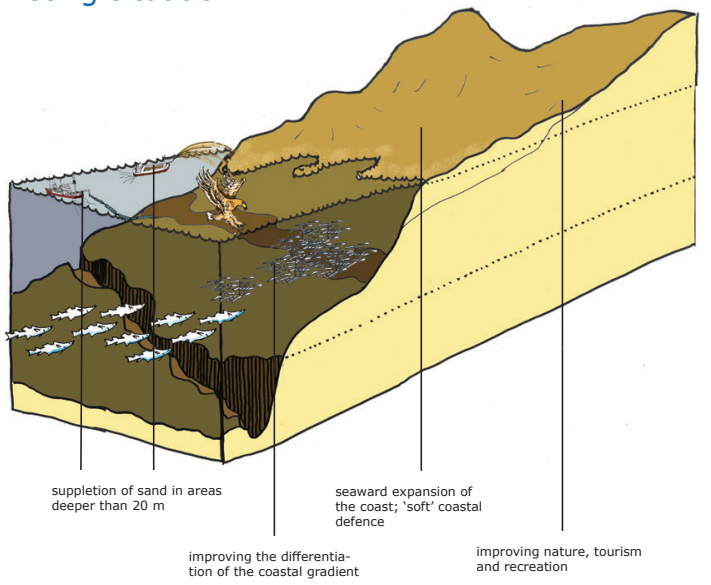

Coast: future situation

\section{Wadden Sea}

Active nature management has preserved the biodiversity of the Wadden Sea (World Heritage Site) as effectively as possible. Resting, moulting and breeding areas, as well as foraging areas, have been designated for the dozens of bird species living on the mud flats. Aided by higher seawater temperatures, more southerly species such as the pullet carpet shell, the short-snouted seahorse, the flamingo, bottlenose dolphin, thornback ray and stingray are becoming more and more visible in the Wadden Sea.

\section{Western Wadden area}

In 2120, part of the western Wadden Sea no longer falls dry at low tide. Some mud flats are permanently under water due to sea level rise. To counter

\section{The coast}

To protect the Dutch coast, hybrid dikes of natural origin, such as dunes and shellfish banks, are being developed and beaches are replenished with sand. The higher the rise in sea level, the more sand needs to be replenished. For an absolute increase of 1.5 metres in 2120, an average of 46 million cubic metres of sand is needed annually, almost four times as much as is currently being replenished. This sand is extracted from the seabed, in elongated channels at a depth of more than 20 meters.

\section{Biodiversity}

The biodiversity in the coastal zone is richer in 2120 than in the previous century. Species such as red mullet, gilt-head bream, anchovy, sea bass, harbour porpoise, bottlenose dolphin and humpback whale are common, and the whitetailed eagle has also found a suitable habitat. By widening the estuaries where river water and sea water mix together, new habitats are created for plants and animals.

\section{Tourism}

The coast is also a major tourist attraction in 2120 . Nature and recreation are being combined more and more sustainably with the replacement of old homes. Additional recreational homes may no longer be built in the coastal areas.

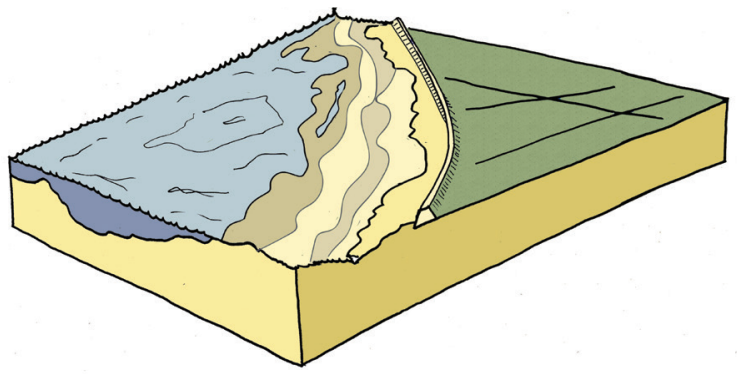

Wadden Sea: existing situation

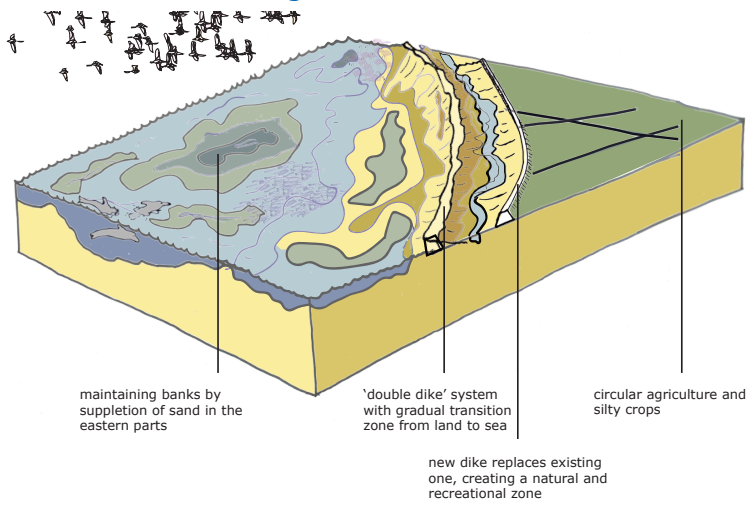

Wadden Sea: future situation 
the serious consequences for fish-eating birds that breed on the tidal flats and for seals that to give birth to and suckle their young, bird island Griend (southwest of Terschelling) and other tidal flats are replenished. Wadden flats still fall dry between Vlieland and Texel, and many birds can be found there. Replenishment of silty clay at Balgzand (the largest tidal flat, east of Den Helder) protects the coast and ensures that the abundant bird life is preserved.

\section{Eastern Wadden area}

Despite the sea level rise, many flats in the eastern Wadden area still fall dry at low tide. On the heads of islands and in the outer deltas there are large sand deposits that are carried by the current towards the Wadden Sea. Due to the accretion and erosion caused by the rise in sea level, the islands are moving towards the Southeast.

\section{Friesland and Groningen}

The mainland coast of Friesland and Groningen is characterised by broad landscapes that hold back the sea instead of narrow dikes and dunes. We encounter mud flats, salt marshes (outside the dikes), broad dikes and herbaceous vegetation that merge into marshes between double dike zones. Salt-loving crops are also grown in brackish areas within the dikes.

\section{Southwestern delta}

The Southwestern delta, including Zeeland, has changed considerably in 2120. It has become a green oasis in the midst of Dutch and Belgian forested cities. The dunes on the North Sea coast have doubled in size. Double dikes also ensure the safety of the inhabitants.

Freshwater agriculture and salt-tolerant agriculture each have their own place. Through waterlogging and the advancing salt water, saline cultivation and aquaculture (shellfish and seaweed) have provided a new, economically successful agricultural perspective.

\section{Western Scheldt}

The Western Scheldt is still an important supply route for the port of Antwerp. Farmland has been replaced by double dike systems. The land between the dikes is used for shellfish and seaweed farming, among other purposes. The freshwater -saltwater transitions in the area have been preserved which benefits biodiversity. Due to natural sludge

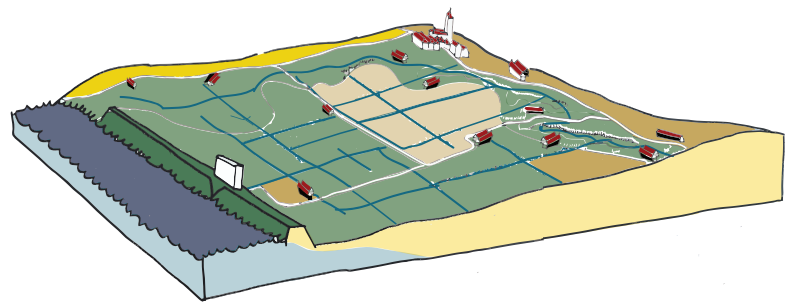

Southwestern delta: existing situation deposition, the land area has grown, which contributes to nature development and water safety.

\section{Eastern Scheldt}

A new storm surge barrier has been built in the mouth of the Eastern Scheldt that allows more water dynamics and enables the growth of sand flats and mud flats. In places where there is no natural growth it is stimulated with small-scale replenishment. Due to a connection with the Western Scheldt, there is more sludge in the system, which brings in more nutrients that benefit flora and fauna. To facilitate the migration routes for fish, the Eastern Scheldt is connected to the Volkerak-Zoommeer by a freshwater-saltwater transition zone. These transition zones are an attractive habitat for unique flora and fauna.

\section{Grevelingen and Haringvliet}

Grevelingen and Haringvliet are connected to the North Sea and rivers, so that freshwater-saltwater transition zones are restored and fish can migrate from sea to river unhindered. This has a positive effect on the populations of many fish species, including rays and sharks, sturgeon and salmon. The biodiversity in the area has increased and rich and varied natural habitats have developed. 


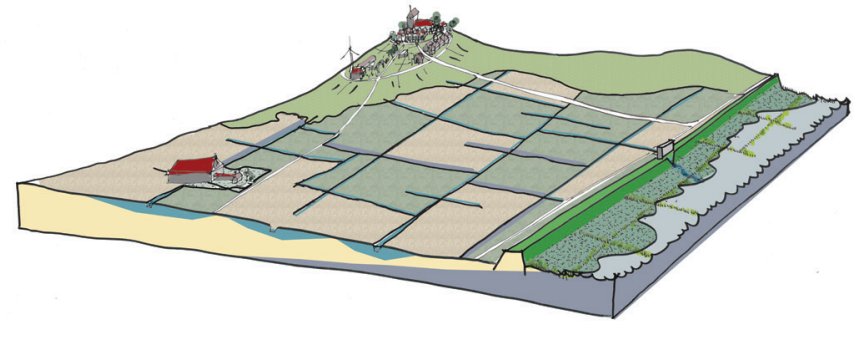

Clay polders in the North of the Netherlands: existing situation

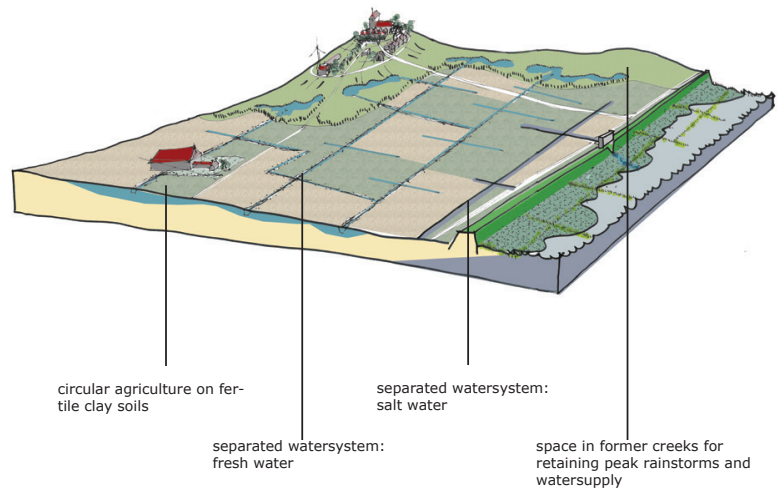

Clay polders in the North of the Netherlands: existing situation

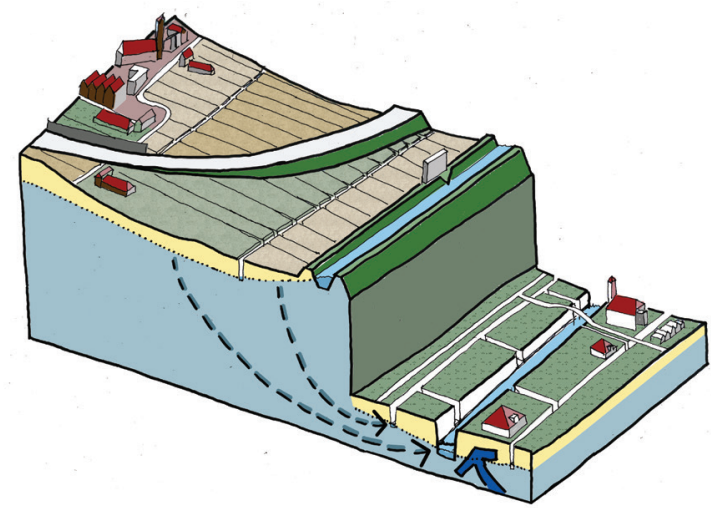

Peat meadows and dry-lake polders: existing situation

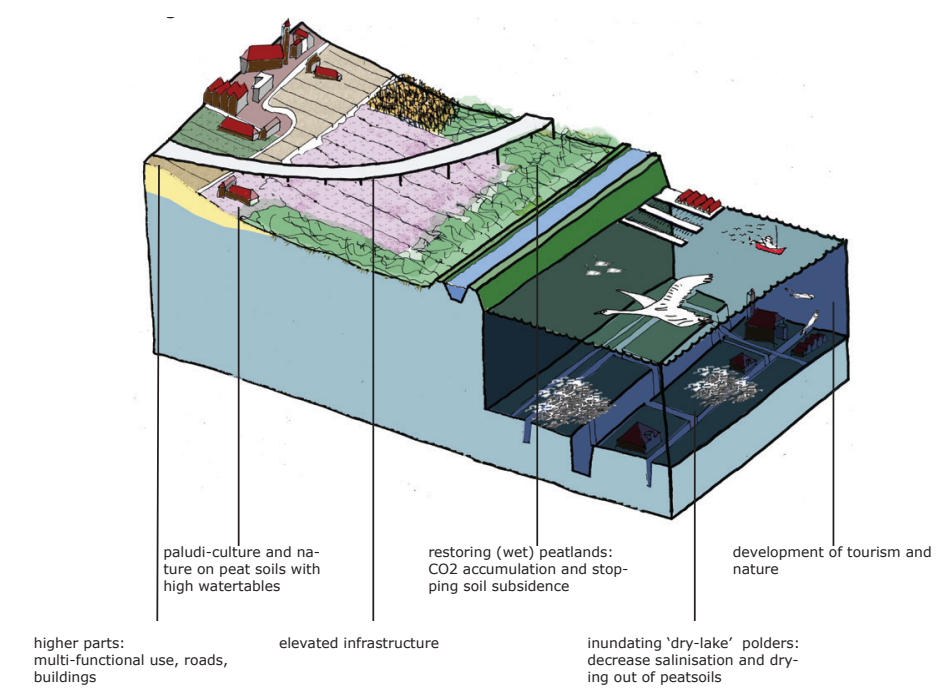

Peat meadows and dry-lake polders: future situation

\section{Northern Netherlands clay soils}

The clay soils in the Northern Netherlands are ideal for high-value circular agriculture. Freshwater basins store the excess rainwater in the winter so that it can be used in the dry summer period. Advancing saltwater is intelligently separated from freshwater with separate watercourses. Freshwater weirs are also used to separate the heavier saltwater from the lighter freshwater. Broad landscapes that hold back the sea ensure water safety in the area. In the most vulnerable low-lying areas, double dikes defend against the sea. The sea deposits sediment between the dikes, which reinforces the dikes. Elsewhere, the flood defences on the landward side are provided with wetland zones that both retain water for agriculture and provide back pressure to counteract rising sea levels.

\section{Peat soil grasslands}

In the western region of the Netherlands extensive peat bogs and large lakes with water-loving crops around urban enclaves exist in 2120 . These are visually attractive areas, located close to international transport hubs. The business climate is good, and tourists like to visit. The former river beds run like green ribbons through the wet peat soil grasslands and are used in many ways for both recreation and small-scale urban agriculture.

\section{Agriculture and livestock farming}

The Netherlands is at the forefront of agriculture on waterlogged and saline soils. Waterlogged soils provide ideal conditions for reed, marsh forest, peat moss and cranberries, and are a suitable habitat for water buffalo. These areas therefore contribute to the production of biomass, fibre, insulation and construction material, potting soil, medicines, animal feed, meat and cheese. In 2120, the inhabitants of North-western Europe consume less meat and dairy products, which means that less land is needed for dairy farming. Dairy farming has responded to this trend at the right time by seeking cooperation with horticulture, aquaculture and agricultural nature management.

Waterlogging of peat soil grasslands provides natural back pressure against saltwater intrusion, and prevents soil subsidence and peat oxidation. It also creates opportunities for new growth of peatlands for sequestering greenhouse gases. Large-scale flushing of polders with precious freshwater is no longer necessary.

\section{Infrastructure}

The new raised infrastructure longer forms a barrier in natural systems and water flows. It is fully geared to extremes such as flooding and is designed and built to function optimally as an evacuation network in case of emergencies. A multifunctional 'green-blue' network has 
been realised in the polders that benefits natural pest control, crop pollination and water buffering in the event of extreme weather.

\section{River areas}

\section{IJssel and Maas}

The rivers in 2120 have an ever-increasing variation in discharge rates. The IJssel, for example, transports extremely large quantities of water from the Rhine to the North. The riverbed of the IJssel has therefore been doubled in width. To compensate for the extreme discharge rates of the Maas, the river dikes have been removed so water can flow through the entire Maas valley again. Homes that were flooded too often have been demolished.

These developments on the IJssel and Maas rivers have also benefitted the restoration of biodiversity in the Netherlands. It is also beneficial because the dikes of the other rivers do not have to be raised. Raising the water table in the marshy zones that are established on the inside of the dikes creates back pressure to counteract high river levels. These broad zones can also store water and enhance biodiversity. The fertile river clay soils provide opportunities for circular agriculture. Besides dairy farming, there is room for arable farming and fruit cultivation.

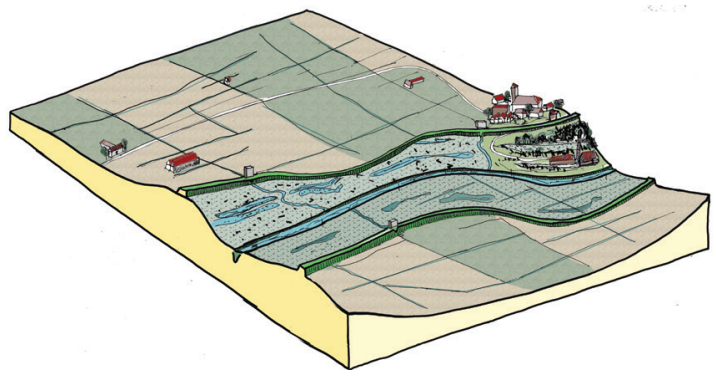

River areas: existing situation

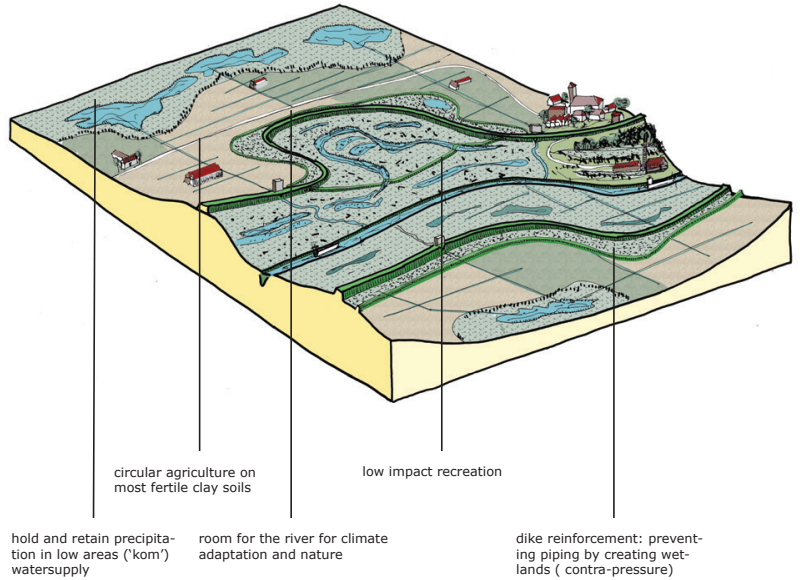

River areas: future situation

\section{Biesbosch}

The Biesbosch has been extended to the west and east, which has increased the water collection capacity of the area. This is necessary due to higher river discharge rates, the higher sea level and the opening of Grevelingen and Haringvliet among other reasons. The Biesbosch has become a wonderful nature area with spawning grounds for twait shad and breeding sites for the osprey. Aided by the rise in temperature, the squacco heron and the Dalmatian pelican can also be seen here. In parts of the Biesbosch there is room for extensive livestock farming.

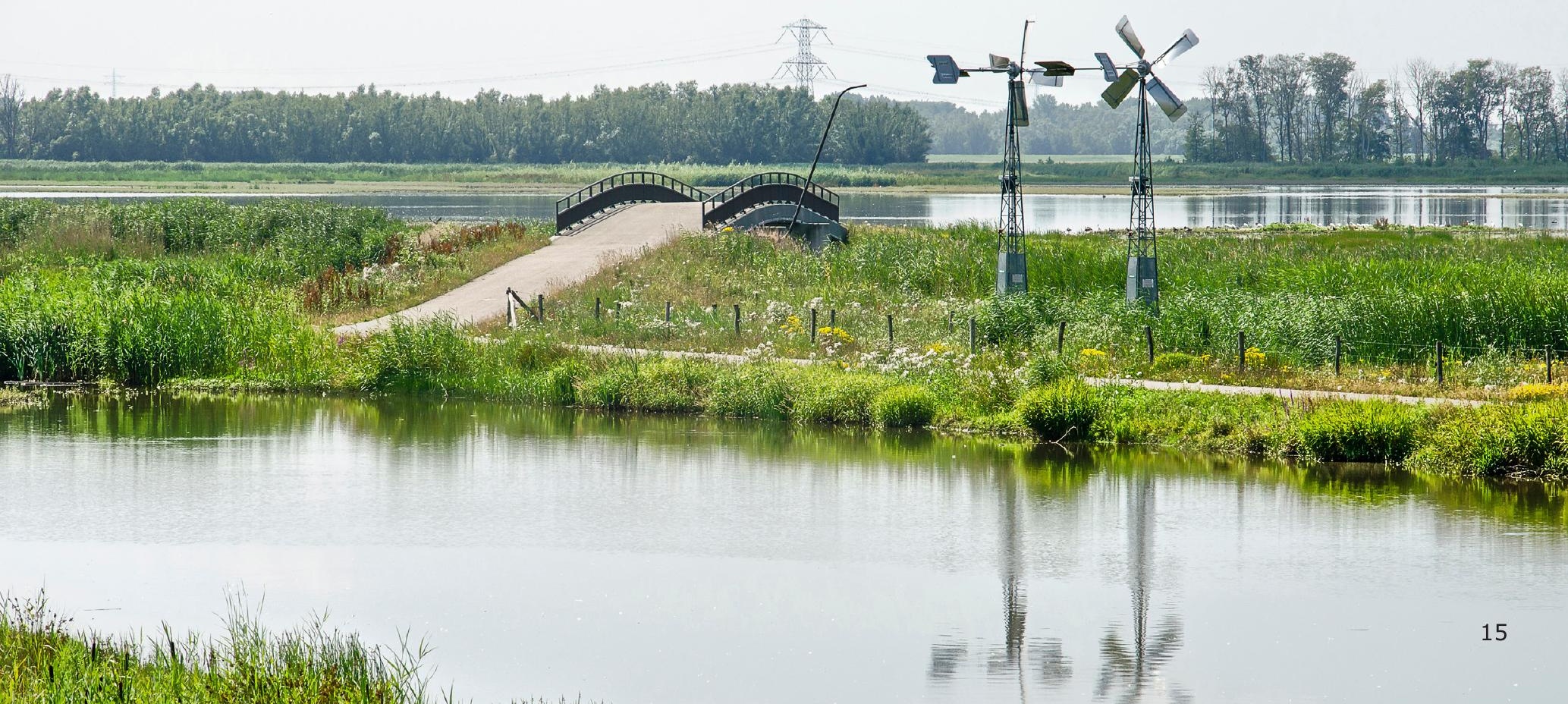




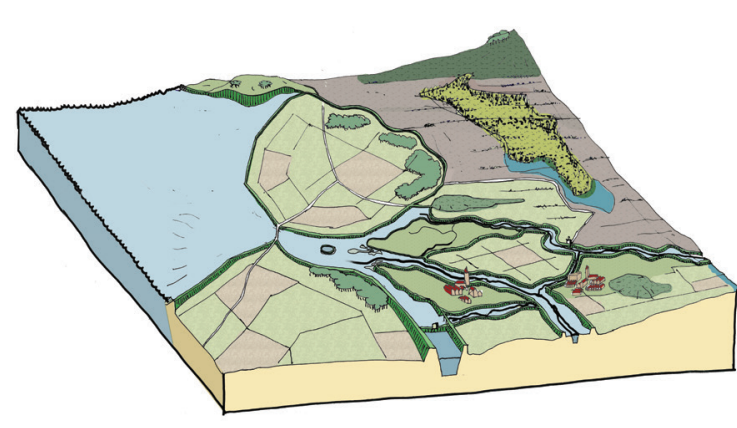

IJsselmeer area: existing situation

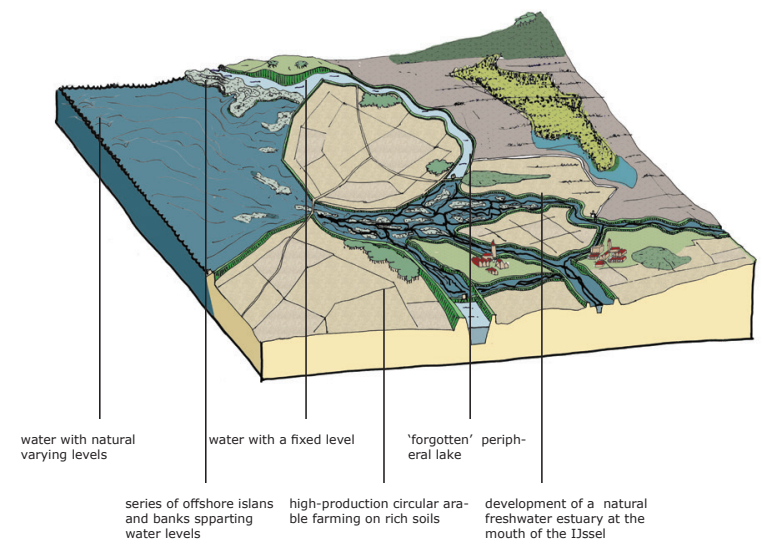

IJsselmeer area: future situation

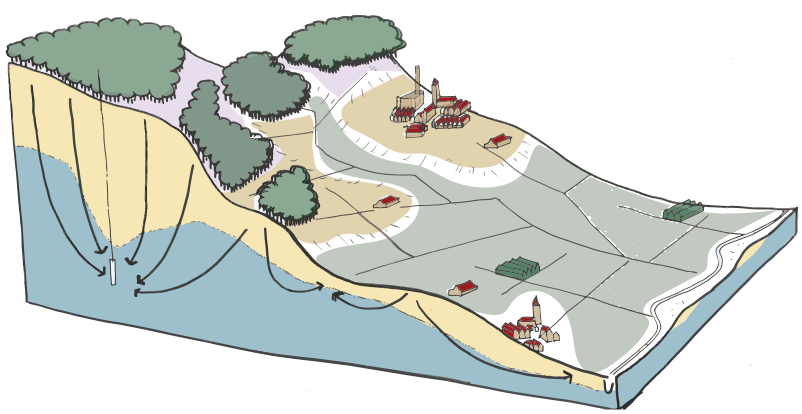

Higher elevation sandy soils: existing situation

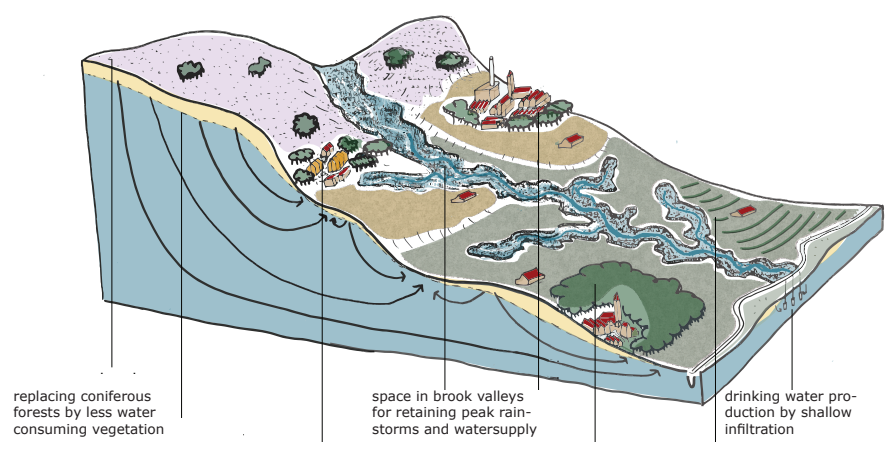

recovery of groundwa- new, 'green' settlements
tersystems and levels located at the rim of hilly

parks and forests in

Higher elevation sandy soils: future situation

\section{IJsselmeer}

The IJssel forms a broad connection to the IJsselmeer and has higher discharge rates. If rivers can no longer discharge due to high tides, the river floodplains offer room for water storage. The IJsselmeer has a double shore zone: a fixed level for shipping on the edges and a natural dynamic level in the centre. The sand for the banks that has been extracted from the IJsselmeer has created deep, cool channels where smelt can retreat in hot summers.

The IJsselmeer is still an important freshwater supply for drinking water and high-value agriculture. Water demand has declined throughout the Netherlands in the decades before 2120, partly due to water-saving cultivation methods and water-saving measures in industry and households. The sea and the IJssel river determine the level and conditions of the IJsselmeer. The Afsluitdijk is still in place, while the Houtribdijk (between Lelystad and Enkhuizen) has been segmented, creating islands connected with bridges. A freshwater delta has developed in the mouth of the IJssel.

\section{Higher elevation sandy soils}

The higher elevation sandy soils are crucial for the hydrological system. By retaining and slowing the flow of rainwater, these soils relieve streams and rivers of excess water during heavy precipitation and peak discharge periods. Groundwater is also supplemented to the maximum.

Regionally, large infiltration areas have been established where rainwater is retained as much as possible instead of draining away. To further promote water infiltration, coniferous forests are being replaced by more open areas with deciduous trees and herbaceous grasslands, as the latter evaporate less water.

In the agricultural areas on the high sandy soils, room has again been created for 'green-blue' veins in the landscape. Stream valleys - with marsh forests if possible - are a good example of this. They increase the biodiversity and resilience of the system, which also benefits circular agriculture. The maximum extension of the watercourses ensures that water drains away more slowly and has a greater chance of infiltrating. By filling in upstream sections of the stream valley, seepage systems are recharged. Near urban areas they offer many possibilities for recreation. In the agricultural areas near cities, farming is combined with cultivation of trees that provide food. Food forests are located near cities where people can not only find food, but also enjoy peaceful nature. 


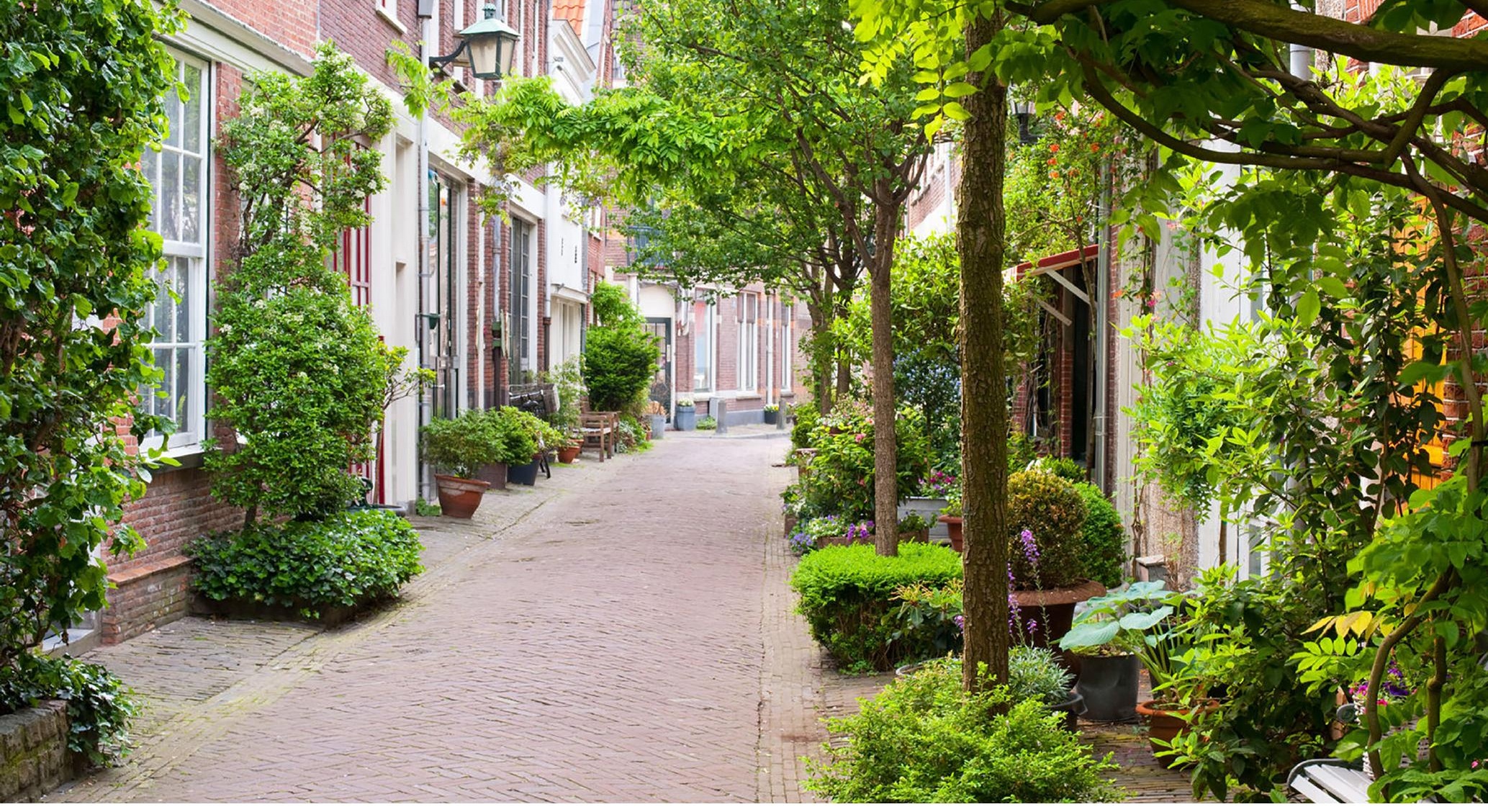

\section{The urban environment}

The design of cities is no longer based on what is technically possible from a civil engineering perspective, but is circular and is based on natural processes, with ample attention to optimising quality of life and climate resilience. Timber construction has become dominant. Rainwater is collected as much as possible on and in buildings, in gardens and in the green public space.

New economic centres are no longer being developed in the Randstad, but on the higher elevation sandy soils; further growth of residential and employment areas is gradually shifting towards the east of the country. This strengthens cooperation with neighbouring German federal states, in particular regarding workforce participation and education. This leads to more economic activity and more urbanisation. The Randstad nevertheless remains a focal point of economic and societal development. This is due to the importance of this region as a port and as a centre of governance, expertise and logistics.

The quality of the landscape, nature and recreation is increasing, and water safety in the Netherlands remains guaranteed. Better 'green-blue' connections are being developed between the city and the countryside. Moreover, the urban area has become forested and bordered by woodlands, including food forests and agroforestry. This is not only to enhance recreational

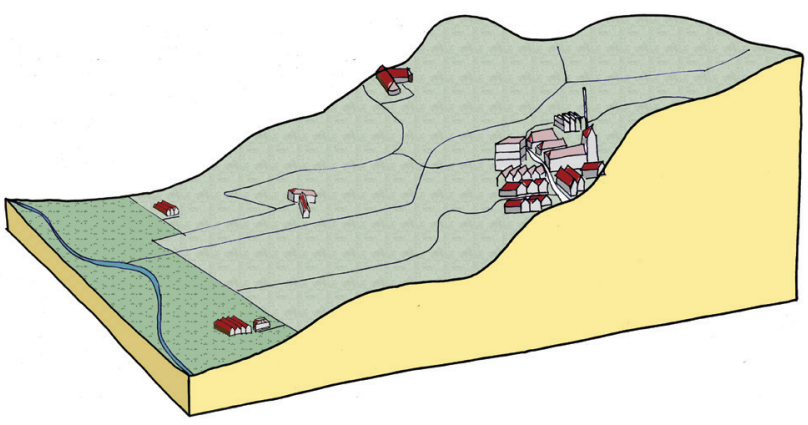

Urban expansion of higher elevation sandy soils: existing situation

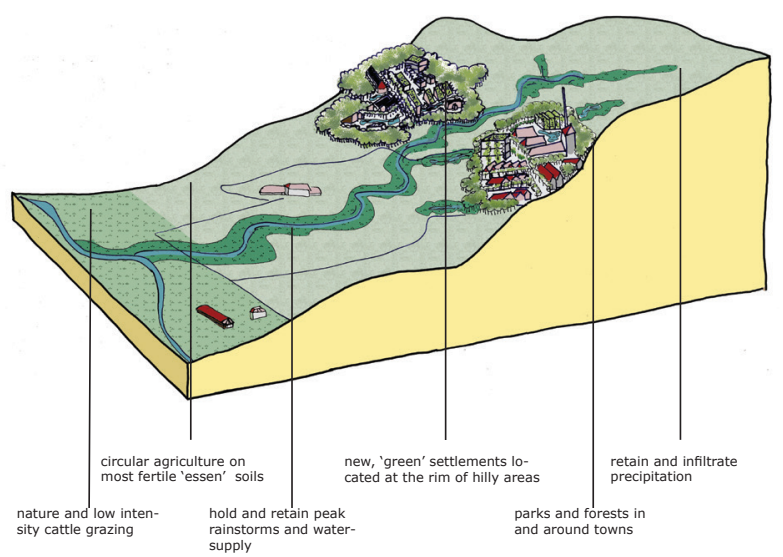

Urban expansion of higher elevation sandy soils: future situation opportunities and biodiversity, but also to reduce the heat island effect in the city. Much open water in and around the city is important for urban water management, contributes to the living environment of inhabitants and enhances the urban climate. The motto is: more wellbeing, less particulate matter. 


\section{Literature used}

Abel, S., Couwenberg, J., Dahms, T. \& Joosten, H. (2013). The Database of Potential Paludiculture Plants (DPPP) and results for Western Pomerania. Plant Div. Evol. 130: 219-228.

Baan, P \& Klijn, F. (1998). De Rijn op termijn; een veerkracht strategie. WL | Delft Hydraulics, rapport R3124.10, Delft.

Bijleveld, K., Bergsma, G. \& Nusselder, S. (2016). Circulaire economie: een belangrijk instrument voor $\mathrm{CO}_{2}$-reductie. CE Delft, Delft.

Born, G.J. van den, Kragt, F., Henkens, D., Rijken, B., van Bemmel, B. \& van der Sluis, S. (2016). Dalende bodems, stijgende kosten, mogelijke maatregelen tegen veenbodemdaling in het landelijk en stedelijk gebied. PBL-publicatienummer 1064. Den Haag, Planbureau voor de Leefomgeving.

FAO (2018). The future of food and agriculture - Alternative pathways to 2050 - Summary version (pp. 60). Roma, Italy.

FAO (2019). Achieving Blue Growth - Building vibrant fisheries and aquaculture communities (pp. 25). Rome, Italy.

Graeter, K.A. et al. (2018). Ice core record of West-Greenland melt and climate forcing, Geoph. Res. Lett., 10.1002/2017GL076641.

Haasnoot, M. et al. (2018). Mogelijke gevolgen van versnelde zeespiegelstijging voor het Deltaprogramma - Een verkenning. Delft, Deltares.

IPBES (2019). Summary for policymakers of the global assessment report on biodiversity and ecosystem services of the Intergovernmental Science-Policy Platform on Biodiversity and Ecosystem Services. S. Díaz, J. Settele, E. S. Brondizio E.S., H. T. Ngo, M. Guèze, J. Agard, A. Arneth, P. Balvanera, K. A. Brauman, S. H. M. Butchart, K. M. A. Chan, L. A. Garibaldi, K. Ichii, J. Liu, S. M. Subramanian, G. F. Midgley, P. Miloslavich, Z. Molnár, D. Obura, A. Pfaff, S. Polasky, A. Purvis, J. Razzaque, B. Reyers, R. Roy Chowdhury, Y. J. Shin, I. J. Visseren-Hamakers, K. J. Willis, and C. N. Zayas (eds.). IPBES secretariat, Bonn, Germany.

IPCC (2018). Global Warming of $1.5^{\circ} \mathrm{C}$. An IPCC Special Report on the impacts of global warming of $1.5^{\circ} \mathrm{C}$ above pre-industrial levels and related global greenhouse gas emission pathways, in the context of strengthening the global response to the threat of climate change, sustainable development, and efforts to eradicate poverty.

IPCC (2019). Summary for Policymakers. In: IPCC Special Report on the Ocean and Cryosphere in a Changing Climate [H.-O. Pörtner, D.C. Roberts, V. Masson-Delmotte, P. Zhai, M. Tignor, E. Poloczanska, K. Mintenbeck, M. Nicolai, A. Okem, J. Petzold, B. Rama, N. Weyer (eds.)]. In press.

I\&W (2015). Beleidsnota Noordzee 2016-2021 (Bijlage 2 Nationaal Waterplan) (pp. 120). Den Haag.

Jong, M.F. de, Borsje, B.W., Baptist, M.J., Wal, J.T van der, Lindeboom, H.J., Hoekstra, P. (2016). Ecosystem-based design rules for marine sand extraction sites. Ecological Engineering 87: 271-280.

Krayenhoff, E.S. et al., (2018). Diurnal interaction between urban expansion, climate change and adaptation in US cities, Nature Climate Change 8: 1097-1103.

Kleinhans, M.G. (2005). Flow discharge and sediment transport models for estimating a minimum timescale of hydrological activity and channel and delta formation on Mars. Journal of Geophysical Research: Planets, 110(E12).

Matthijsen, J., Dammers, E., \& Elzenga, H. (2018). De toekomst van de Noordzee - De Noordzee in 2030 en 2050: een scenariostudie. Den Haag: Planbureau voor de Leefomgeving.

Ministerie van Infrastructuur en Waterstaat (2019), Brief aan voorzitter van de Tweede Kamer der Staten-Generaal. Betreft Plastic Pact NL. Datum 20 februari 2019

Wang, Z.B., Elias, E.P., van der Spek, A.J., \& Lodder, Q.J. (2018). Sediment budget and morphological development of the Dutch Wadden Sea: impact of accelerated sea-level rise and subsidence until 2100. Netherlands Journal of Geosciences, 97(3): 183-214.

Wichtmann, W. et al. (2016). Paludiculture - productive use of wet peatlands. Stuttgart, Schweizerbart Science Publishers. Xu, Y. et al. (2018). Global Warming will happen faster than we think. Nature 564: 30-32. doi: 10.1038/d41586-018-07586-5. 


\section{Credits}

December 2019

\section{Authors}

Martin Baptist, Tim van Hattum, Stijn Reinhard, Michaël van Buuren, Bertram de Rooij, Xiaolu Hu, Sabine van Rooij, Nico Polman, Sander van den Burg, GerJan Piet, Tom Ysebaert, Brenda Walles, Jeroen Veraart, Wieger Wamelink, Bram Bregman, Bram Bos \& Trond Selnes.

https://doi.org/10.18174/512277

Wageningen University \& Research combines fundamental and applied knowledge based on its mission 'To explore the potential of nature to improve the quality of life'. In this way WUR contributes to solving important questions in the field of healthy food and living environment. Our 5,500 employees and more than 12,000 students are inspired by nature, society and technology, inspiration that has enabled us for more than a century to marvel, to develop knowledge and to apply it worldwide. And we do not do this alone, but as much as possible together with government agencies and public bodies, the business community, non-governmental organisations and other universities and research institutes.

www.wur.nl 
